\title{
Nýjungar og áskoranir í læknanámi á tímum rafrænna stökkbreytinga
}

Pað er vel pekkt í heimi vísindanna að tækninýjungar leiða oft til örra breytinga. Nú eru 60 efstu próftakar í inntökuprófi læknadeildar teknir inn á fyrsta ár í stað 48 fyrir fjórum árum. Рað hefur í för með sér ákveðnar breytingar á umgjörð námsins og á síðasta áratug hefur Háskóli Íslands stigið æ fleiri skref inn í heim rafrænna prófa og kennsluhátta. Рað gerðist fyrst með námsumsjónarforritum eins og Uglu og Moodle, síðar með upptökuforritinu Panoptó og prófaforritinu Inspera. Nokkurrar tregðu gætti pó gagnvart notkun Panoptó og Inspera meðal kennara af ýmsum ástæðum.

Á fyrstu stigum COVID-19 heimsfaraldursins í vor breyttist pessi tregða tafarlaust í létti pegar nauðsynlegt reyndist að færa staðkennslu í skyndi í rafræna fjarkennslu. Miklu breytti að hópfundaforritin Zoom og Teams höfðu verið að ryðja sér til rúms til fjarfunda, miðlunar skjala í mynd og upptöku. Jafnframt purfti að breyta námsmati vormisseris par sem kennslustofum og lesstofum Háskólans var lokað á seinni hluta misserisins. Lokapróf voru pví flest preytt í opnu umhverfi í Inspera heima hjá nemendum. Ameríska CCSE-lokaprófið á 6. ári var til dæmis preytt á heimilum nema með myndbandsvöktun. Að auki purfti hluti nema að vinna verkefni í stað verklegra tilrauna, finna purfti leiðir til að ræða við nemendur um klíník utan sjúkradeilda að loknum stofugangi og gera myndbönd um ákveðna pætti verknáms. Loks má nefna að í ágúst var námsumsjónarforritið Canvas innleitt í skólanum og eru kennarar og nemendur óðum að tileinka sér möguleika pess.

Á síðasta áratug hefur aðgengi að fjölbreyttu námsefni aukist hratt á veraldarvefnum. Pví má segja að pörfin fyrir að nemar mæti í hefðbundna fyrirlestra sé minni en áður, nema pá helst til að glæða skilning peirra á aðalatriðum og samhengi, gefa peim kost á að spyrja og vitaskuld til að hittast og kynnast hvert öðru betur. Staðnám er pví sérstaklega mikilvægt pegar nýnemar eiga í hlut. Í pessu samhengi er rétt að nefna að mikil áhersla er nú lögð á að læknanemar og aðrir nemar í heilbrigðisvísindum efli færni sína í samskiptum við sjúklinga, aðstandendur og samstarfsfólk.

Um pessar mundir eru 14\% landsmanna fædd utan Íslands. Sjúklingar, par á meðal einstaklingar frá framandi menningarheimum, kvarta sumir undan pví að íslenskir heilbrigðisstarfsmenn gætu gert

betur í samskiptum. Par koma meðal annars upp atriði eins og að við mættum bera meiri virðingu fyrir eldra fólki, fólki með annan menningarbakgrunn, geðraskanir eða óljósar kvartanir sem pekki ekki kerfið hér og að notkun túlks sé í boði. Heitorð lækna áréttar að læknar skuli ávallt láta sér annt um alla sjúklinga sína án manngreinarálits. Samhliða kröfunni um aukna samskiptafærni og heildrænni nálgun, er skýrari krafa í heilbrigðispjónustu um aukna stöðlun í vinnubrögðum, meiri afköst og hlutlægari leiðir til að öðlast færni, til að mynda með herminámi, beinu mati á frammistöðu og fleiri verkferlum fyrir algeng vandamál.

Ýmislegt fleira má telja til nýjunga. Nú er hægt að skrá sig í doktorsnám samhliða námi til kandídatsprófs að loknu priðja námsári, í svokallaða MD-PhD-doktorsnámsnámsleið. Nýr samstarfsvettvangur er orðinn til fyrir nema í rannsóknartengdu doktorsnámi í klínískri læknisfræði, erfðafræði, faraldsfræði

Nú eru 60 manns tekin inn í læknadeild árlega, og gamla afríska máltækið að pað purfti heilt porp til að̃ ala upp barn er í fullu gildi. og lýðheilsuvísindum til að efla innviði námsins. Prír óvirkir gamlir sjóðir voru sameinaðir á síðasta ári og Menntasjóður læknadeildar stofnaður. Fimm læknanemar hlutu styrk úr honum á árinu vegna rannsóknarverkefna erlendis á 3. ári. Læknadeild á nú í spennandi samstarfi við læknadeild Hafnarháskóla og fleiri aðila um próun opins netnámskeiðs fyrir 6. árs læknanema í einstaklingsmiðuðum lækningum (personalised medicine).

Læknanemar hafa sjálf staðið fyrir ýmsum nýjungum. Pau hófu í haust hlaðvarp, Dagál læknanemans, um algenga sjúkdóma og meðferð peirra, og á Instagram-síðunni islenskirlaeknanemar kynna pau nú nám sitt í ýmsum löndum og dagleg störf lækna.

Раð parf heilt porp til að ala upp barn segir afrískt máltæki. Til að skapa góðan lækni parf vissulega gott uppeldi, fjölbreytta færnipjálfun og margháttaða reynslu á starfsferlinum. Раð skiptir miklu að temja sér auðmýkt í starfi, hafa áhuga á fólki og læra að meta mátt samtalsins. Ekki sakar að geta slegið á létta strengi pegar viðá, maður er manns gaman. Að endingu vil ég nefna að réttlætiskennd, símenntun og pjálfun í gagnrýnni hugsun eru verðandi læknum ómetanlegt veganesti til að vinna gegn meðvirkni og hjarðhegðun. evolution

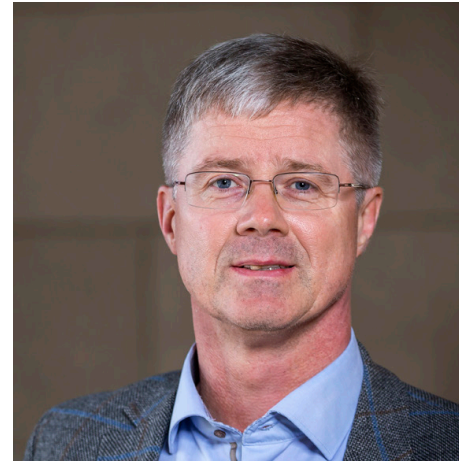

\section{Engilbert Sigurōsson}

geðlæknir á Landspítala, forseti læknadeildar Háskóla Íslands

engilbs@landspitali.is
Innovations and challenges in medical education in times of burgeoning software

Engilbert Sigurdsson MD MSc

Dean of the Faculty of Medicine

Professor of Psychiatry Consultant Psychiatrist at Landspitali-University Hospital

Faculty of Medicine

School of Health Sciences University of Iceland 